\title{
Polyphenol content in cold-pressed cakes of conventional and genetically modified flax as factor affecting stability of the product in different laboratory storage conditions
}

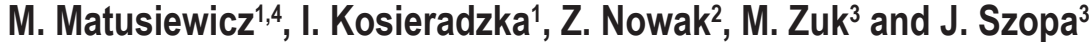 \\ Warsaw University of Life Sciences - SGGW, Faculty of Animal Sciences, ' Department of Animal Nutrition and Biotechnology, \\ ${ }^{2}$ Department of Genetics and Animal Breeding, Ciszewskiego 8, $02-786$ Warsaw, Poland \\ ${ }^{3}$ University of Wrockaw, Faculty of Biotechnology, Department of Genetic Biochemistry \\ Przybyszewskiego 63/77, 51-148 Wrockaw, Poland
}

KEY WORDS: GMO, flax, cold-pressed cake, phenolic acids, secoisolariciresinol diglucoside, storage

Received: $\quad 7$ July 2015

Revised: 26 February 2017

Accepted: 9 March 2017

${ }^{4}$ Corresponding author:

e-mail: magdalena_matusiewicz@sggw.pl
ABSTRACT. Polyphenol compounds were analysed and storage stability determined of cold-pressed cakes from one non-genetically modified (non-GM) flax variety Linola and two GM lines: W92 line with overexpressed flavonoid biosynthesis pathway and GT line with overexpressed glycosyltransferase. The $20 \mathrm{~g}$ samples of each cake were stored in oxygen-free and dark conditions for 3 (T3) and 7 (T7) months at 4 and $21^{\circ} \mathrm{C}$. Initial (T0), and T3 and T7 samples were analysed for phenolic acids, phenolic acid glucosides and secoisolariciresinol diglucoside (SDG) content, and peroxide, free fatty acids and 2-thiobarbituric acid (TBA) values; total viable counts (TVC) and counts of yeast and moulds were also determined. At T0, T3 and T7, contents of all phenolic compounds were higher in both GM than non-GM cakes and in all cakes most of them were slightly decreased at T3 and more at T7. At T0 peroxide, free fatty acid and TBA values were lower in GM than in non-GM cake (particularly of TBA in W92 with the highest initial SDG content) indicating their better initial fat quality. Small changes of the indices reflecting fat deterioration during storage seemed, however, to be not dependent on polyphenol content. The TVC at T0, T3 and T7/4 ${ }^{\circ} \mathrm{C}$ were the smallest in W92 cake and did not change in a regular way in non-GM and GT cakes. Yeast counts were low in all cakes over the whole storage period and mould counts were the smallest in W92 cake. It may be concluded that protective properties of flax polyphenols, especially of SDG present in W92, were more apparent prior to than during cake storage.

\section{Introduction}

Flaxseeds are successfully used as food and feed (Żuk et al., 2011; Mercier et al., 2014). Among the types of flax are Linola seeds, which have high unsaturated fatty acid (UFA) contents, i.e. linoleic acid (C18:2), oleic acid (C18:1) and less than 5\% $\alpha$-linolenic acid (C18:3) (Żuk et al., 2011). The high concentration of polyunsaturated fatty acids (PUFAs) accelerates their oxidation (Żuk et al., 2011). Flaxseeds are the richest dietary source of 
important nutrients and polyphenols like lignans, mainly secoisolariciresinol, and phenolic acids, present as glycosides. Polyphenols have a wide range of health-promoting properties and act as antioxidants protecting also flax lipids from oxidative deterioration during the seed storage (Matusiewicz et al., 2015). Polyphenols escape cold oil pressing from flaxseeds and are present in the flax cake - a by-product of the process. Flax cake has a high nutrient and energy contents and is utilized for production of functional foods and feeds, value-added products (Żuk et al., 2011; Matusiewicz et al., 2015).

The enhancement of polyphenols in the flax seeds is possible using genetic engineering strategies. The simultaneous overexpression of three cDNAs, derived from Petunia hybrida, coding for flavonoid biosynthesis pathway enzymes (W92 line) or the overexpression of glycosyltransferase from Solanum sogarandinum (GT line) result in a higher expression of polyphenols and their glycosides and an improved antioxidant capacity and accumulation of UFAs in the seeds (Lorenc-Kukuła et al., 2009; Żuk et al., 2011).

Flax cake deterioration, the important consequence of lipid oxidation, is stimulated by several factors including time and storage conditions. These factors provoke changes of food quality, including the formation of off-flavours and rancidity. Lipid oxidation leads to the production of hydroperoxides, which are subsequently transformed into volatile and non-volatile secondary oxidation products (Barriuso et al., 2013).

Bacteriostatic and fungistatic properties of polyphenols influencing food and feed stability were found also in flaxseeds (Manthey et al., 2008). The microbial stability of flaxseeds could be increased by the overexpression of polyphenols. This was achieved in genetically modified (GM) flax, W92 and GT, which inhibited the growth of some plant fungal pathogens (Lorenc-Kukuła et al., 2009).

The objective of this study was to compare storage stability of two GM flax cakes: W92 and GT with the conventional non-GM variety stored in different laboratory storage conditions. The contents of the phenolic acids, including their glucosides, the secoisolariciresinol diglucoside (SDG), the selected indicators of the fat quality as well as the microbial stability of the cakes were determined.

\section{Material and methods}

\section{Plant material}

The seeds of the non-GM flax (Linum usitatissimum L. cv. Linola 947) were obtained from the Flax and Hemp Collection of the Institute of Natural Fibres and Medicinal Plants (Poznań, Poland). The GM W92 and GT lines were supplied by the Department of Genetic Biochemistry (University of Wrocław, Wrocław, Poland). The procedures of obtaining GM flax, estimating fatty acid composition in seeds and other bioactive compound concentrations in seeds and cakes were made accordingly to Lorenc-Kukuła et al. (2009) and Żuk et al. (2011). The GM and Linola plants were grown in a field within the Wrocław vicinity (trial No. 26, AM-13; decision of the Polish Ministry of the Environment No. 36/2011 form $29^{\text {th }}$ September 2011). The sixth generation of the W92 seeds and the fifth generation of the GT seeds were collected in August 2012 after 4 months of plant cultivation.

\section{Preparation and storage of cakes}

To obtain flax cakes, $25 \mathrm{~kg}$ of seeds were cold pressed in an industrial worm gear oil press (OilPress DD85G, IBG Monoforts Oekotec GmbH \& Co., Mönchengladbach, Germany).

The cake samples were taken for determination of their initial (T0) composition and for storing at 4 and $21^{\circ} \mathrm{C}$ for 3 (T3) and 7 (T7) months. The $20 \mathrm{~g}$ samples, each representing one temperature//time treatment, were stored in a darkness in sterile plastic bags without access to oxygen. At T0, T3 and T7, phenolic acids, phenolic acid glucosides, SDG, indicators of fat quality (peroxide value, acid value, and 2-thiobarbituric acid (TBA) value) and microbiological stability parameters (total viable counts (TVC), count of yeasts and moulds) were determined. Fat contents in the cakes were analysed.

\section{Determination of phenolic compounds and fat quality indicators}

Dry matter of the cakes was determined according to AOAC International (2012). The polyphenol concentration was determined by the ultra-performance liquid chromatography (Żuk et al., 2011) in 3 repetitions.

Crude fat was extracted and determined by the Soxhlet method (AOAC International, 2012). The peroxide value, i.e. the hydroperoxide content, was determined according to the Cd 8b-90 (AOCS, 2004) method and the acid value, free fatty acids (FFA) according to the Ca 5a-40 (AOCS, 2004) method.

TBA values were determined by the method disclosed by Pokorny and Dieffenbacher (1989), by which the secondary oxidation products of fats are quantified. Fat quality indicators were determined in 3 repetitions. 


\section{Determination of microbiota counts}

Ten grams of flax cake samples from each variant of storage conditions were subjected to microbiota analysis.

Total viable counts (TVC), e.g., bacteria, yeasts and moulds, were carried out according to the ISO 4833:2003 method. The determination of yeast and mould counts followed the ISO 21527-2:2008 protocol.

TVC and counts of yeasts and moulds were presented as the number of colony-forming units per gram of cakes $\left(\mathrm{CFU} \cdot \mathrm{g}^{-1}\right)$. The methods are accredited by the Polish Centre for Accreditation (PCA AB 439). The number of repetitions was 2.

\section{Statistical analysis}

The results were expressed as the mean values \pm the standard error of the mean (SEM). The contents of different polyphenols and different fat quality indicators in cakes of different lines, at the beginning of the experiment or after storage at 4 or $21^{\circ} \mathrm{C}$, for 3 or 7 months, were analysed by a three-way (flax line - time - temperature) analysis of variance (GLM-ANOVA) with mean values compared using
Tukey's post-hoc test and NIR correction. Software PS IMAGO PRO 4/IBM SPSS Statistics 24 (Predictive Solutions/IBM, Armonk, NY, USA) was applied. The differences were considered statistically significant at $P<0.05$.

\section{Results and discussion}

\section{Phenolic acid, phenolic acid glucoside and secoisolariciresinol diglucoside (SDG) contents}

Dry matter content did not differ among the cakes and was 94.2 and $94.9 \%$ in Linola and both GM cakes, respectively. In all cakes and over all treatments the SDG was present in the greatest amounts followed by caffeic acid and caffeic acid glucoside, the smallest was the content of coumaric acid (Table 1). Initial (T0) concentrations of all compounds were higher in both GM than in Linola cake. Contents of all acids, SDG, and ferulic and caffeic acid glucosides were higher in W92 than in GT cake (except the lower content of coumaric acid glucoside) which indicates greater efficiency of the

Table 1. Contents of polyphenols and polyphenol glucosides in three flaxseed cakes at the beginning of the experiment (T0) and after 3 and 7 months of storage (T3 and T7, respectively), at 4 and $21^{\circ} \mathrm{C}, \mathrm{g} \cdot \mathrm{kg}^{-1}$ fresh matter

\begin{tabular}{|c|c|c|c|c|c|c|c|c|}
\hline $\begin{array}{l}\text { Time, } \\
\text { months }\end{array}$ & $\begin{array}{l}\text { Temperature, } \\
{ }^{\circ} \mathrm{C}\end{array}$ & $\begin{array}{l}\text { Coumaric } \\
\text { acid }\end{array}$ & $\begin{array}{l}\text { Coumaric acid } \\
\text { glucoside }\end{array}$ & Ferulic acid & $\begin{array}{l}\text { Ferulic acid } \\
\text { glucoside }\end{array}$ & Caffeic acid & $\begin{array}{l}\text { Caffeic acid } \\
\text { glucoside }\end{array}$ & $\mathrm{SDG}^{1}$ \\
\hline \multicolumn{9}{|l|}{ Linola } \\
\hline 0 & 21 & $0.024 \pm 0.001$ & $0.48 \pm 0.01$ & $0.123 \pm 0.020$ & $0.14 \pm 0.00$ & $1.4 \pm 0.1$ & $1.3 \pm 0.0$ & $9.9 \pm 0.4$ \\
\hline \multirow{2}{*}{3} & 4 & $0.024 \pm 0.000$ & $0.40 \pm 0.02$ & $0.099 \pm 0.005$ & $0.14 \pm 0.00$ & $1.1 \pm 0.0$ & $1.2 \pm 0.0$ & $9.7 \pm 0.4$ \\
\hline & 21 & $0.024 \pm 0.001$ & $0.45 \pm 0.01$ & $0.102 \pm 0.004$ & $0.14 \pm 0.02$ & $1.4 \pm 0.0$ & $1.3 \pm 0.1$ & $7.8 \pm 0.2$ \\
\hline \multirow{2}{*}{7} & 4 & $0.021 \pm 0.001$ & $0.37 \pm 0.02$ & $0.093 \pm 0.007$ & $0.13 \pm 0.01$ & $1.1 \pm 0.0$ & $1.2 \pm 0.1$ & $8.9 \pm 0.2$ \\
\hline & 21 & $0.015 \pm 0.007$ & $0.38 \pm 0.03$ & $0.084 \pm 0.005$ & $0.12 \pm 0.01$ & $1.4 \pm 0.1$ & $1.2 \pm 0.1$ & $6.5 \pm 0.4$ \\
\hline \multicolumn{9}{|l|}{ W92 } \\
\hline 0 & 21 & $0.078 \pm 0.001$ & $0.61 \pm 0.01$ & $0.263 \pm 0.014$ & $0.60 \pm 0.01$ & $1.9 \pm 0.0$ & $3.3 \pm 0.0$ & $26.8 \pm 0.5$ \\
\hline \multirow{2}{*}{3} & 4 & $0.075 \pm 0.001$ & $0.56 \pm 0.03$ & $0.249 \pm 0.017$ & $0.60 \pm 0.01$ & $2.5 \pm 0.0$ & $3.3 \pm 0.0$ & $20.4 \pm 0.6$ \\
\hline & 21 & $0.059 \pm 0.006$ & $0.59 \pm 0.01$ & $0.213 \pm 0.016$ & $0.60 \pm 0.01$ & $2.5 \pm 0.1$ & $3.2 \pm 0.1$ & $17.0 \pm 0.7$ \\
\hline \multirow{2}{*}{7} & 4 & $0.069 \pm 0.001$ & $0.50 \pm 0.02$ & $0.226 \pm 0.011$ & $0.53 \pm 0.00$ & $2.4 \pm 0.0$ & $3.3 \pm 0.0$ & $18.1 \pm 0.4$ \\
\hline & 21 & $0.041 \pm 0.003$ & $0.48 \pm 0.01$ & $0.172 \pm 0.014$ & $0.49 \pm 0.00$ & $2.0 \pm 0.0$ & $3.2 \pm 0.0$ & $16.5 \pm 0.5$ \\
\hline \multicolumn{9}{|l|}{ GT } \\
\hline 0 & 21 & $0.053 \pm 0.002$ & $0.94 \pm 0.04$ & $0.172 \pm 0.007$ & $0.42 \pm 0.04$ & $1.7 \pm 0.0$ & $3.0 \pm 0.1$ & $14.8 \pm 0.2$ \\
\hline \multirow{2}{*}{3} & 4 & $0.047 \pm 0.002$ & $0.87 \pm 0.02$ & $0.174 \pm 0.009$ & $0.20 \pm 0.01$ & $1.8 \pm 0.1$ & $1.5 \pm 0.0$ & $14.3 \pm 0.2$ \\
\hline & 21 & $0.043 \pm 0.003$ & $0.94 \pm 0.07$ & $0.168 \pm 0.015$ & $0.27 \pm 0.08$ & $1.9 \pm 0.1$ & $1.7 \pm 0.1$ & $12.1 \pm 0.2$ \\
\hline \multirow{2}{*}{7} & 4 & $0.041 \pm 0.002$ & $0.75 \pm 0.01$ & $0.152 \pm 0.013$ & $0.19 \pm 0.00$ & $1.6 \pm 0.0$ & $1.5 \pm 0.0$ & $12.7 \pm 0.1$ \\
\hline & 21 & $0.038 \pm 0.004$ & $0.45 \pm 0.03$ & $0.096 \pm 0.004$ & $0.23 \pm 0.01$ & $1.5 \pm 0.0$ & $1.6 \pm 0.1$ & $11.3 \pm 0.3$ \\
\hline \multicolumn{9}{|c|}{ Main effects, $P$} \\
\hline \multicolumn{2}{|c|}{ flaxseed } & 0.000 & 0.000 & 0.000 & 0.000 & 0.000 & 0.000 & 0.000 \\
\hline \multicolumn{2}{|c|}{ time } & 0.000 & 0.000 & 0.000 & 0.000 & 0.000 & 0.000 & 0.000 \\
\hline \multicolumn{2}{|c|}{ temperature } & 0.000 & 0.108 & 0.001 & 0.507 & 0.247 & 0.454 & 0.000 \\
\hline \multicolumn{2}{|c|}{ flaxseed $\times$ time } & 0.003 & 0.000 & 0.105 & 0.004 & 0.000 & 0.000 & 0.000 \\
\hline \multicolumn{2}{|c|}{ flaxseed $\times$ temperature } & 0.000 & 0.002 & 0.051 & 0.122 & 0.000 & 0.027 & 0.489 \\
\hline \multicolumn{2}{|c|}{ time $\times$ temperature } & 0.139 & 0.000 & 0.062 & 0.380 & 0.007 & 0.451 & 0.151 \\
\hline \multicolumn{2}{|c|}{ all } & 0.382 & 0.000 & 0.470 & 0.950 & 0.118 & 0.886 & 0.120 \\
\hline
\end{tabular}

${ }^{1} \mathrm{SDG}$ - secoisolariciresinol diglucoside; mean values $\pm \mathrm{SEM} ; \mathrm{n}=3$ 
flaxseed modification via overexpression of three cDNAs derived from Petunia hybrida.

The higher polyphenol content in cakes produced from genetically modified flax is in agreement with other studies (Źuk et al., 2011; Matusiewicz et al., 2015) and confirms the potential of the engineering methods of flavonoid modification in this plant and, as the consequence, in the by-products of oil pressing.

The effect of storage duration on concentration of particular polyphenol compounds differed among the varieties (interaction of flaxseed $\times$ time significant for all polyphenols except ferulic acid) (Table 1) but higher contents of polyphenols in GM cakes has been maintained at T3 and T7. Generally, storage for 7 months decreased content of polyphenols to greater extent than during 3 months. The most stable appeared to be caffeic acid in all cakes and caffeic acid glucoside in Linola and W92. Content of caffeic acid in W92 cake was even higher in all stored samples than in T0 sample, and in GT cake it was higher in samples stored for 3 months. Content of SDG, the prevalent compound, was the lowest in all cakes stored for 7 months at $21^{\circ} \mathrm{C}$ and was reduced to 66, 62 and 76\% in Linola, W92 and GT cakes, respectively. Storage temperature had significant effect on contents of coumaric and ferulic acids and SDG which were lower in cakes stored at 21 than $4{ }^{\circ} \mathrm{C}$.

Our results concerning smaller losses of majority of polyphenols in cakes stored at lower than higher temperature are in line with those of Bravi et al. (2011) who found that the SDG and total phenol contents in flax oil were at maximum level in samples stored for 90 days at $4{ }^{\circ} \mathrm{C}$.

It may be concluded that storage for 3 months at $4{ }^{\circ} \mathrm{C}$ is not detrimental for the polyphenol content both in conventional and GM flax cakes whereas prolongation of the storage till 7 months at higher temperature decreases contents of these compounds.

\section{Indicators of fat quality}

The ether extract content was similar in all cakes and amounted 145, 149 and $150 \mathrm{~g} \cdot \mathrm{kg}^{-1} \mathrm{DM}$ in Linola, W92 and GT cakes, respectively.

Initial peroxide, acid and TBA values were higher in Linola than in W92 and GT cakes, the greatest difference was found for TBA $(1.50,0.5$ and $0.99 \mathrm{mmol} \cdot \mathrm{kg}^{-1}$ of Linola, W92 and GT cakes, respectively; Table 2). Storage duration and temperature significantly affected all values but the effects on particular parameters were irregular and differed among the cakes (interactions flax $\times$ time
Table 2. Fat quality indicators in three flax cakes at the beginning of the experiment (T0) and after 3 and 7 months of storage (T3 and T7, respectively), at 4 and $21^{\circ} \mathrm{C}$

\begin{tabular}{|c|c|c|c|c|}
\hline $\begin{array}{l}\text { Time, } \\
\text { months }\end{array}$ & $\begin{array}{l}\text { Temperature, } \\
{ }^{\circ} \mathrm{C}\end{array}$ & $\begin{array}{l}\text { Peroxide } \\
\text { value, } \\
\mathrm{meq} \cdot \mathrm{kg}^{-1}\end{array}$ & $\begin{array}{l}\text { Acid value, } \\
\%\end{array}$ & $\begin{array}{l}\mathrm{TBA}^{1} \text { value, } \\
\mathrm{mmol} \cdot \mathrm{kg}^{-1}\end{array}$ \\
\hline \multicolumn{5}{|l|}{ Linola } \\
\hline 0 & 21 & $1.9 \pm 0.0$ & $8.3 \pm 0.1$ & $1.50 \pm 0.02$ \\
\hline \multirow{2}{*}{3} & 4 & $2.5 \pm 0.0$ & $8.4 \pm 0.0$ & $1.60 \pm 0.01$ \\
\hline & 21 & $3.1 \pm 0.0$ & $8.6 \pm 0.0$ & $1.70 \pm 0.02$ \\
\hline \multirow{2}{*}{7} & 4 & $1.4 \pm 0.0$ & $8.5 \pm 0.0$ & $1.68 \pm 0.01$ \\
\hline & 21 & $3.2 \pm 0.0$ & $8.8 \pm 0.1$ & $1.98 \pm 0.02$ \\
\hline \multicolumn{5}{|l|}{ W92 } \\
\hline 0 & 21 & $1.5 \pm 0.2$ & $7.4 \pm 0.1$ & $0.50 \pm 0.03$ \\
\hline \multirow{2}{*}{3} & 4 & $2.3 \pm 0.0$ & $8.1 \pm 0.0$ & $0.60 \pm 0.02$ \\
\hline & 21 & $2.7 \pm 0.0$ & $8.2 \pm 0.1$ & $0.67 \pm 0.01$ \\
\hline \multirow{2}{*}{7} & 4 & $2.5 \pm 0.0$ & $8.3 \pm 0.1$ & $0.65 \pm 0.02$ \\
\hline & 21 & $2.8 \pm 0.0$ & $8.3 \pm 0.0$ & $0.76 \pm 0.01$ \\
\hline \multicolumn{5}{|l|}{ GT } \\
\hline 0 & 21 & $1.5 \pm 0.1$ & $7.3 \pm 0.0$ & $0.99 \pm 0.05$ \\
\hline \multirow{2}{*}{3} & 4 & $3.9 \pm 0.0$ & $7.7 \pm 0.0$ & $1.00 \pm 0.01$ \\
\hline & 21 & $4.6 \pm 0.0$ & $7.8 \pm 0.0$ & $1.20 \pm 0.02$ \\
\hline \multirow{2}{*}{7} & 4 & $2.9 \pm 0.0$ & $7.9 \pm 0.0$ & $1.01 \pm 0.02$ \\
\hline & 21 & $3.1 \pm 0.0$ & $7.9 \pm 0.1$ & $1.28 \pm 0.03$ \\
\hline \multicolumn{5}{|c|}{ Main effects, $P$} \\
\hline \multicolumn{2}{|c|}{ flaxseed } & 0.000 & 0.000 & 0.000 \\
\hline \multicolumn{2}{|c|}{ time } & 0.000 & 0.000 & 0.000 \\
\hline \multicolumn{2}{|c|}{ temperature } & 0.000 & 0.000 & 0.000 \\
\hline \multicolumn{2}{|c|}{ flaxseed $\times$ time } & 0.000 & 0.006 & 0.001 \\
\hline \multicolumn{2}{|c|}{ flaxseed $\times$ temperature } & 0.000 & 0.029 & 0.001 \\
\hline \multicolumn{2}{|c|}{ time $\times$ temperature } & 0.029 & 0.568 & 0.001 \\
\hline \multicolumn{2}{|c|}{ all } & 0.000 & 0.711 & 0.054 \\
\hline
\end{tabular}

${ }^{1}$ TBA - 2-thiobarbituric acid; mean values \pm SEM; $n=3$

significant for all compounds except ferulic acid). Peroxide values were generally higher in all stored than in T0 samples except that in the Linola cake it was decreased to $1.4 \mathrm{meq} \cdot \mathrm{kg}^{-1}$ in samples stored for 7 months at $4{ }^{\circ} \mathrm{C}$. The effect of time and temperature on peroxide value was the smallest and regular in W92 cake whereas in GT cake peroxide values in samples stored for 7 months were also lower than in those stored for 3 months ( 2.9 vs 3.9 and 3.1 vs $4.6 \mathrm{meq} \cdot \mathrm{kg}^{-1}$ in samples stored at 4 and $21{ }^{\circ} \mathrm{C}$, respectively). The decrease of peroxide values in samples stored for longer time may be explained by the degrading of the fat peroxides and not by inhibition of their formation. The effect of storage duration and temperature on acid value was relatively small. The TBA values were increased both by duration and temperature of storage and in all cakes the highest values were found in samples stored for 7 months at $21^{\circ} \mathrm{C}$. 
The results of our experiment do not evidence the protecting role of polyphenols against oxidation of flax cake fat during storage. However, all parameters showed a better initial fat quality of GM cakes containing more polyphenols which may suggest their earlier protective effects. Particularly the lowest initial value of TBA in W92 cake showing the highest SDG content, may be an argument.

\section{Total viable counts (TVC) and yeast and moulds counts}

At T0, the TVC in W92 cake was the smallest, stayed at a low level during 3 months storage, and was greatly increased in sample stored for 7 months at 21 but not at $4{ }^{\circ} \mathrm{C}$ (Table 3 ). The initial TVC were similar in Linola and GT and changed slightly in rather irregular way. Yeasts were present in all cakes in small amounts and were not affected by storage conditions, count of moulds was low and the lowest and stable in W92 cake.

Table 3. Total viable, yeast and mould counts in Linola, W92 and GT flax cakes at the beginning of the experiment (TO), after 3 and 7 months of storage ( $\mathrm{T} 3$ and $\mathrm{T} 7$, respectively), at 4 and $21^{\circ} \mathrm{C}, \mathrm{n}=2$

\begin{tabular}{|c|c|c|c|c|c|}
\hline \multirow{2}{*}{$\begin{array}{l}\text { Microbiota, } \\
\mathrm{CFU} \cdot \mathrm{g}^{-1}\end{array}$} & \multirow{2}{*}{$\begin{array}{l}\text { Time, } \\
\text { months }\end{array}$} & \multirow{2}{*}{$\begin{array}{l}\text { Temperature, } \\
{ }^{\circ} \mathrm{C}\end{array}$} & \multicolumn{3}{|c|}{ Flax cakes } \\
\hline & & & Linola & W92 & GT \\
\hline \multirow{5}{*}{$\begin{array}{l}\text { Total viable } \\
\text { counts }\end{array}$} & 0 & 21 & $5.5 \times 10^{5}$ & 560 & $6.1 \times 10^{5}$ \\
\hline & \multirow{2}{*}{3} & 4 & $9.0 \times 10^{4}$ & 82 & $1.2 \times 10^{5}$ \\
\hline & & 21 & $1.2 \times 10^{5}$ & 110 & $7.1 \times 10^{4}$ \\
\hline & \multirow{2}{*}{7} & 4 & $7.8 \times 10^{4}$ & 740 & $1.1 \times 10^{5}$ \\
\hline & & 21 & $1.2 \times 10^{5}$ & $1.8 \times 10^{5}$ & $3.5 \times 10^{5}$ \\
\hline \multirow[t]{5}{*}{ Yeasts } & 0 & 21 & $<10$ & $<10$ & $<10$ \\
\hline & \multirow{2}{*}{3} & 4 & $<40$ & $<10$ & $<40$ \\
\hline & & 21 & $<10$ & $<10$ & $<10$ \\
\hline & \multirow{2}{*}{7} & 4 & $<10$ & $<10$ & $<40$ \\
\hline & & 21 & $<10$ & $<10$ & $<40$ \\
\hline \multirow[t]{5}{*}{ Moulds } & 0 & 21 & 90 & $<10$ & 60 \\
\hline & \multirow{2}{*}{3} & 4 & $<40$ & $<10$ & 40 \\
\hline & & 21 & 120 & $<10$ & $<40$ \\
\hline & \multirow{2}{*}{7} & 4 & 50 & $<10$ & $<40$ \\
\hline & & 21 & 60 & $<10$ & 70 \\
\hline
\end{tabular}

Relative stability of TVC and low yeasts and moulds counts in the cakes indicates bacteriostatic and fungistatic properties of flaxseed. Similar properties of the whole flax seeds were reported by Manthey et al. (2008) who found that pasta enriched with flaxseed flour had lower microbial, mould and yeast counts than traditional product when stored over 7 weeks at $4{ }^{\circ} \mathrm{C}$. The smallest TVC and mould counts found in our study in W92 cake with the highest SDG content may suggest implication of polyphenols. The increased resistance of the GM flax to some fungal pathogens was reported by Lorenc-Kukuła et al. (2009).

\section{Conclusions}

Genetical modifications of flax generate increased content of polyphenol compounds in cakes produced by cold oil pressing. Study performed on the small-size samples of genetically modified (GM) and non-GM flax cakes allows to conclude that polyphenol content is reduced to a lesser extent by storage for 3 months at $4{ }^{\circ} \mathrm{C}$ and in greater extent during 7 months and at $21^{\circ} \mathrm{C}$, the higher polyphenol content in the GM than non-GM cakes being maintained. Polyphenols do not appear to affect changes of fat quality or bacteriostatic and fungistatic properties of flax cakes during storage but their earlier influence may be assumed from differences between initial values of several indices in the high secoisolariciresinol diglucoside GM and non-GM cakes.

\section{Acknowledgements}

This work was supported by the National Science Centre, Poland, Project No. N N311 526540.

\section{References}

AOAC International, 2012. Official Methods of Analysis of AOAC International. $19^{\text {th }}$ Edition. Gaithersburg, MD (USA)

AOCS, 2004. Official Methods and Recommended Practices of the American Oil Chemists' Society. $5^{\text {th }}$ Editon. Champaign, IL (USA)

Barriuso B., Astiasarán I., Ansorena D., 2013. A review of analytical methods measuring lipid oxidation status in foods: a challenging task. Eur. Food Res. Technol. 236, 1-15, https://doi.org/10.1007/s00217-012-1866-9

Bravi E., Perretti G., Marconi O., Patrizi E., Fantozzi P., 2011. Secoisolariciresinol diglucoside determination in flaxseed (Linum usitatissimum L.) oil and application to a shelf life study. Food Chem. 126, 1553-1558, https://doi.org/10.1016/j. foodchem.2010.11.169

ISO 21527-2:2008. Microbiology of food and animal feeding stuffs Horizontal method for the enumeration of yeasts and moulds - Part 2: Colony count technique in products with water activity less than or equal to 0.95 . International Standards Organization. Geneva (Switzerland)

ISO 4833:2003. Microbiology of food and animal feeding stuffs Horizontal method for the enumeration of microorganisms - Colony-count technique at $30^{\circ} \mathrm{C}$. International Standards Organization. Geneva (Switzerland)

Lorenc-Kukuła K., Zuk M., Kulma A., Czemplik M., Kostyn K., Skala J., Starzycki M., Szopa J., 2009. Engineering flax with the GT family 1 Solanum sogarandinum glycosyltransferase SsGT1 confers increased resistance to Fusarium infection. J. Agric. Food Chem. 57, 6698-6705, https://doi.org/10.1021/ jf900833k

Manthey F.A., Sinha S., Wolf-Hall C.E., Hall C.A. III, 2008. Effect of flaxseed flour and packaging on shelf life of refrigerated pasta. J. Food Process. Preserv. 32, 75-87, https://doi. org/10.1111/j.1745-4549.2007.00166.x 
Matusiewicz M., Kosieradzka I., Sobczak-Filipiak M., Zuk M., Szopa J., 2015. Transgenic flax overexpressing polyphenols as a potential anti-inflammatory dietary agent. J. Funct. Foods 14, 299-307, https://doi.org/10.1016/j.jf.2015.02.004

Mercier S., Villeneuve S., Moresoli C., Mondor M., Marcos B., Power K.A., 2014. Flaxseed-enriched cereal-based products: a review of the impact of processing conditions. Comp. Rev. Food Sci. Food Saf. 13, 400-412, https://doi.org/10.1111/15414337.12075
Pokorny J., Dieffenbacher A., 1989. Determination of 2-thiobarbituric acid value: direct method - results of a collaborative study and the standarised method. Pure Appl. Chem. 61, 1165-1170, https://doi.org/10.1351/pac198961061165

Żuk M., Kulma A., Dymińska L., Szołtysek K., Prescha A., Hanuza J., Szopa J., 2011. Flavonoid engineering of flax potentiate its biotechnological application. BMC Biotechnol. 11, 10, https:// doi.org/10.1186/1472-6750-11-10 